\title{
INCREASING DETECTION SENSITIVITY OF LOW COPY NUMBER TRANSCRIPTS THROUGH PREAMPLIFICATION OF CDNA MOLECULES
}

\author{
Pantelis Dimaras, Oskan Tasinov, Desislava Ivanova, Yoana Kiselova-Kaneva, \\ Diana Ivanova \\ Department of Biochemistry, Molecular Medicine and Nutrigenomics, \\ Faculty of Pharmacy, Medical University of Varna
}

\begin{abstract}
With the advances in the field of molecular biology and its applications in the clinical practice during the recent years, it has become crucial to perform molecular analyses on limited amount of tissue obtained through biopsies. Additionally, tissue is fixed in formalin and further embedded in paraffin (FFPE), a procedure which causes extensive degradation of nucleic acids, mainly RNAs. Furthermore, when studying gene expression profiles of a set of genes, which present physiologically low expression, the number of transcripts is low and cannot be detected. In this study we focus on amplifying effectively cDNA molecules synthesized from small amounts of initial RNA before analyzing the expression levels through quantitative polymerase chain reaction (qPCR). By introducing the preamplification step in the procedure, we achieved highly efficacious detection and quantification of expression levels of low-expression genes.
\end{abstract}

Keywords: cDNA preamplification, $q P C R$, gene expression

\section{INTRODUCTION}

As a part of many standard diagnostic procedures, the implication of a tissue biopsy is mandatory for detection and confirmation of the right diagnosis. Tissue sampling is performed quite often by minimally invasive procedures such as punch biopsies or needle aspiration biopsies (1). The quantity of the biological material is in most of the cases satisfactory for histological and cytological studies. However, with the advances in the field of molecular diagnostics and research possibilities, it is requested

Address for correspondence:

Pantelis Dimaras

Department of Biochemistry, Molecular Medicine and

Nutrigenomics

Faculty of Pharmacy

Medical University of Varna

84 Tzar Osvoboditel Blvd, Varna

e-mail:pantedimaras@yahoo.gr

Received: April 6, 2017

Accepted: June 5, 2017 to perform molecular analyses on already limited amount of tissue (2). In addition, most of the times the tissue is fixed in formalin and embedded in paraffin (FFPE) to present the morphological features of the tissue. The disadvantage of this procedure is the extensive degradation of nucleic acids mostly of RNA and the formation of nucleoprotein complexes, which limit greatly the amount of molecules suitable for detection and analysis (3). An effective method for increasing detection sensitivity is the addition of a preamplification step before gene expression analysis through qPCR (4). Many studies confirm the accuracy of the preamplification step, which is applied on cDNA template synthesized by reverse transcription (5-8). Furthermore, the preamplification procedure is a modified version of conventional PCR. It consists of a small number of cycles, as well as increased annealing temperature and low primer concentration in order to ensure high specificity of amplification of target cDNAs (9). The reduced number of cycles re- 
Pantelis Dimaras, Oskan Tasinov, Desislava Ivanova et al.

duces the risk of modifying expression levels leading to altered results (4).

The aim of this study was to assess the efficiency of preamplification of cDNA molecules synthesized from low quantity and degraded RNA samples from FFPE tissue biopsies.

\section{MATERIALS AND METHODS RNA isolation}

Tissue sections from FFPE were placed in 1.5 $\mathrm{ml}$ microcentrifuge tube and concomitantly deparaffinization was performed. A volume of $1 \mathrm{ml}$ xylene was added, followed by a brief vortex and spin at maximum speed for $2 \mathrm{~min}$ at room temperature. Xylene was then removed by pipetting. The pelleted tissue was then washed from residual xylene by adding $1 \mathrm{ml}$ of $100 \%$ ethanol. Samples were briefly mixed by vortex followed by spin for $2 \mathrm{~min}$ at room temperature. Deparaffinized tissue was left to air dry with open tubes. A volume of $100 \mu$ l of Quickextract FFPE RNA extraction Lysis buffer (Epicentre, Illumina, USA) was added to the tissue sample. Samples were incubated at $56^{\circ} \mathrm{C}$ for $30 \mathrm{~min}$ and further heated to $80^{\circ} \mathrm{C}$ for $10 \mathrm{~min}$. Then, $1 \mathrm{~mL}$ of Accuzol (Bioneer, Republic of Korea) solution was added. Samples were mixed by vortex and incubated at room temperature for $8 \mathrm{~min}$. Then $200 \mu \mathrm{l}$ of chloroform were added. Samples were mixed by vortex and allowed to sit for $2 \mathrm{~min}$ and centrifuged for phase separation at $12.000 \mathrm{~g}$ at $4^{\circ} \mathrm{C}$ for $15 \mathrm{~min}$. The aqueous phase was transferred to a new clear $1.5 \mathrm{ml}$ microcentrifuge tube and an equal volume of absolute ethanol was added and mixed. Samples were transferred to RNA Clean and Concentrator 5 spin columns (Zymo Research, USA) and RNA was purified according to manufacturers' protocol and finally eluted to $15 \mu \mathrm{l}$ volume HPLC grade $\mathrm{H}_{2} \mathrm{O}$.

\section{RNA quantification through spectrophotometry}

RNA sample yield and purity were calculated by spectrophotometry measuring absorptions at 260 , 280 and 320nm using Take3 plate of Synergy 2 instrument (Biotek, USA). At $260 \mathrm{~nm}$ wavelength nucleic acids readily absorb the emitted light energy and at $280 \mathrm{~nm}$ the proteins. The $320 \mathrm{~nm}$ absorption value is measured as an internal blank.

\section{Reverse transcription}

In order to synthesize cDNA molecules, 500ng total RNA template and water were added to a final volume of $10 \mu$ l. To this volume $1 \mu$ l containing 15 pmol of gene specific reverse primer for genes SIRT6, FOXO4 and HIF3A (Table 1) was added. Samples were heated to $65^{\circ} \mathrm{C}$ for $5 \mathrm{~min}$ and then cooled down to $4^{\circ} \mathrm{C}$ for $5 \mathrm{~min}$ in a thermal cycler GeneAmp PCR System 9700 (Applied Biosystems, USA). Then $4 \mu \mathrm{l}$ Reaction buffer $(250 \mathrm{mM}$ Tris- $\mathrm{HCl}, 250 \mathrm{mM} \mathrm{KCl}$, $20 \mathrm{mM} \mathrm{MgCl}_{2}, 10 \mathrm{mM}$ DTT) were added to each sample, $1 \mu$ l RNase inhibitor (20U), $2 \mu$ d dNTPs (10mM) and $1 \mu \mathrm{l}$ Revertaid reverse transcriptase (200U) (Thermo Scientific, USA) to a final volume of $20 \mu \mathrm{l}$ according to manufacturers' instructions. Samples were incubated at $45^{\circ} \mathrm{C}$ for $60 \mathrm{~min}$ followed by inactivation at $70^{\circ} \mathrm{C}$ for $5 \mathrm{~min}$ and stored at $-20^{\circ} \mathrm{C}$.

\section{Preamplification}

Samples were preamplified in a final $50 \mu \mathrm{l}$ PCR reaction volume for each sample. Template $\mathrm{CDNA}$ of $5 \mu$ l volume was used per reaction. $5 \mu \mathrm{l}$ of Taq DNA polymerase buffer containing $\mathrm{MgCl}_{2}, 2 \mu \mathrm{dNTPs}$ $(2.5 \mathrm{mM})$, mix of forward and reverse primers for genes of interest to a final concentration of $50 \mathrm{nM}$ each (Table 1), 2U of Taq DNA polymerase (New England Biolabs, USA) and water were added to the reaction. Samples were amplified in a thermal cycler GeneAmp PCR System 9700 (Applied Biosystems, USA). Initial denaturation was performed at $95^{\circ} \mathrm{C}$ for $5 \mathrm{~min}$, followed by $95^{\circ} \mathrm{C}$ for $15 \mathrm{sec}$ and $60^{\circ} \mathrm{C}$ for $4 \mathrm{~min}$

Table 1. Primer sequences targeting transcript of SIRT6, FOXO4 and HIF3A genes

\begin{tabular}{lllc} 
Primers & Forward & Reverse & Primer bank ID \\
$\begin{array}{l}\text { SIRT6- } \\
\text { 194bp }\end{array}$ & CCCACGGAGTCTGGACCAT & CTCTGCCAGTTTGTCCCTG & $300797596 \mathrm{c1}$ \\
$\begin{array}{l}\text { FOXO4- } \\
113 \mathrm{bp}\end{array}$ & CCGGAGAAGCGACTGACAC & CGGATCGAGTTCTTCCATCCTG & $283436081 \mathrm{c2}$ \\
$\begin{array}{l}\text { HIF3A- } \\
\text { 156bp }\end{array}$ & GGGAAGGTGTCTCTGTGTTTC & CCTCGTTGTGCTCAATGCAG & $326807023 \mathrm{c2}$ \\
\hline
\end{tabular}


for 5 cycles. Samples were finally cooled down to $4^{\circ} \mathrm{C}$ and stored at $-20^{\circ} \mathrm{C}$.

\section{Quantitative PCR}

Samples were analyzed with the assistance of real-time quantitative PCR. Per reaction $4 \mu \mathrm{l}$ of $20 \mathrm{X}$ diluted in water preamplified or non-preamplified cDNA product was added. Then, $5 \mu$ l of Maxima SYBR Green qPCR Master Mix (Thermo Scientific, USA) were added, containing ROX passive reference dye and primers to a final concentration of $0.25 \mu \mathrm{M}$ in total $10 \mu \mathrm{l}$ reaction. Amplification was performed with initial denaturation step at $95^{\circ} \mathrm{C}$ for $10 \mathrm{~min}$ followed by $95^{\circ} \mathrm{C}$ for $15 \mathrm{sec}$ denaturation and $63^{\circ} \mathrm{C}$ annealing-extension step for $1 \mathrm{~min}$ for 40 cycles. Melting curve analysis was also performed from $60^{\circ} \mathrm{C}$ to $95^{\circ} \mathrm{C}$ gradually by $0.5^{\circ} \mathrm{C}$ increments on an instrument ABI7500 (Applied Biosystems, USA). Analyses were performed in triplicates.

\section{Statistical analysis}

All data presented have been processed using GraphPad Prism V6 and Microsoft Excel 2013 software. For the estimation of statistical significance, Student's $t$-test as performed with $p<0.05$ was considered as significant.

Table 2. Mean $\triangle C$ Ct values from three samples obtained through two-step Real-Time qPCR between non-preamplified and preamplified cDNA samples. Data are presented as mean $\pm S D$.

\begin{tabular}{|c|c|c|c|c|}
\hline \multicolumn{5}{|l|}{ SIRT6 } \\
\hline sample & $\begin{array}{c}\mathrm{Ct} \\
\text { non-preamplified }\end{array}$ & $\begin{array}{c}\mathrm{Ct} \\
\text { preamplified }\end{array}$ & $\left(\mathrm{Ct}_{\text {preA }} \stackrel{\Delta \mathrm{Ct}}{\left.-\mathrm{Ct} t_{\text {non-preA }}\right)}\right.$ & $p$-value \\
\hline 1 & $16.82 \pm 0.09$ & $16.03 \pm 0.02$ & -0.795 & 0.0060 \\
\hline 2 & $18.29 \pm 0.06$ & $17.09 \pm 0.04$ & -1.20 & 0.0004 \\
\hline 3 & $19.86 \pm 0.35$ & $18.52 \pm 0.44$ & -1.34 & 0.0539 \\
\hline \multicolumn{5}{|l|}{ FOXO4 } \\
\hline sample & $\begin{array}{c}\mathrm{Ct} \\
\text { non-preamplified }\end{array}$ & $\begin{array}{c}\mathrm{Ct} \\
\text { preamplified }\end{array}$ & $\left(\mathrm{Ct}_{\text {preA }}-\mathrm{Ct}_{\text {non-preA }}\right)$ & $p$-value \\
\hline 1 & $17.62 \pm 0.06$ & $16.39 \pm 0.06$ & -1.24 & 0.0009 \\
\hline 2 & $19.77 \pm 0.15$ & $17.28 \pm 0.10$ & -2.49 & 0.0002 \\
\hline 3 & $21.76 \pm 0.36$ & $19.80 \pm 0.19$ & -1.96 & 0.0052 \\
\hline \multicolumn{5}{|l|}{ HIF3A } \\
\hline sample & $\begin{array}{c}\mathrm{Ct} \\
\text { non-preamplified }\end{array}$ & $\begin{array}{c}\mathrm{Ct} \\
\text { preamplified }\end{array}$ & $\left(\mathrm{Ct}_{\text {preA }}-\mathrm{Ct}_{\text {non-preA }}\right)$ & $p$-value \\
\hline 1 & $16.54 \pm 0.14$ & $15.93 \pm 0.13$ & -0.61 & 0.0591 \\
\hline 2 & $18.58 \pm 0.06$ & $17.15 \pm 0.05$ & -1.43 & 0.0011 \\
\hline 3 & $21.07 \pm 0.13$ & $20.17 \pm 0.12$ & -0.90 & 0.00002 \\
\hline
\end{tabular}


Pantelis Dimaras, Oskan Tasinov, Desislava Ivanova et al.

reaction to enhance selectively amplicons of low copy number gene transcripts.

According to our study, preamplification results in significantly lower Ct values for genes presenting limited expression. Taking into consideration the 10X dilution of the initial cDNA template for amplification and 5 cycles of preamplification, we would expect ideally a $\Delta \mathrm{Ct}$ value of 2 . However, the values lower or higher than 2 indicate that the preamplification efficiency is lower or higher than $100 \%$, respectively.

Preamplification provides an effective and efficient way to increase the sensitivity of detection. All $\Delta \mathrm{Ct}$ values were close to the expected 2 values. This procedure can be applied with confidence to samples from which tissue specimen is limited. The major advantage is that preamplification eliminates the need of additional discomforting biopsy procedures for the patients for genetic studies, since it increases sample capacity for additional analyses from the already obtained biologic material.

\section{CONCLUSION}

Preamplification increases the time for sample preparation before analysis through quantitative PCR. However, it proves to be an effective and accurate method to increase detection sensitivity in limited sample size and quantity.

\section{REFERENCES}

1. Lejnine S, Marton MJ, Wang IM, Howell BJ, Webber AL, Maxwell JW, et al. Gene expression analysis in serial Liver fine needle aspirates. J Viral Hepat. 2014;22(1):64-76. doi: 10.1111/jvh.12213

2. Austin MC, Smith C, Pritchard CC, Tait JF. DNA yield from tissue samples in surgical pathology and minimum tissue requirements for molecular testing. Arch Pathol Lab Med. 2016;140(2):130-3. doi: 10.5858/arpa.2015-0082-OA

3. von Ahlfen S, Missel A, Bendrat K, Schlumpberger $M$. Determinants of RNA quality from FFPE samples. PLoS One. 2007;2(12): e1261. doi: 10.1371/journal.pone.0001261

4. Andersson D, Akrap N, Svec D, Godfrey TE, Kubista M, Landberg G, et al. Properties of targeted preamplification in DNA and cDNA quantification.

Expert Rev Mol Diagn [Internet]. 2015;15(8):1085100. Available from: http://www.pubmedcentral. nih.gov/articlerender.fcgi?artid= 4673511 \&tool=pmcentrez\&rendertype $=$ abstract. doi: 10.1586/14737159.2015.1057124

5. Noutsias M, Rohde M, Block A, Klippert K, Lettau O, Blunert K, et al. Preamplification techniques for real-time RT-PCR analyses of endomyocardial biopsies. BMC Mol Biol. 2008;9(DCM):3. doi: 10.1186/1471-2199-9-3

6. Zeka F, Vanderheyden K, De Smet E, Cuvelier C a., Mestdagh P, Vandesompele J. Straightforward and sensitive RT-qPCR based gene expression analysis of FFPE samples. Sci Rep [Internet]. 2016;6(February):21418. Available from: http://www.nature.com/articles/srep21418\%5Cnhttp://www. ncbi.nlm.nih.gov/pubmed/26898768\%5Cnhttp:// www.pubmedcentral.nih.gov/articlerender. fcgi?artid=PMC4761903. doi: 10.1038/srep21418

7. Baak-Pablo R, Dezentje V, Guchelaar H-J, van der Straaten T. Genotyping of DNA samples isolated from formalin-fixed paraffin-embedded tissues using preamplification. J Mol Diagn [Internet]. 2010;12(6):746-9. Available from: http://www. pubmedcentral.nih.gov/articlerender.fcgi?artid $=29$ 63916\&tool=pmcentrez\&rendertype $=$ abstract. doi: 10.2353/jmoldx.2010.100047

8. Kroneis T, Jonasson E, Andersson D, Dolatabadi S, Ståhlberg A. Global preamplification simplifies targeted mRNA quantification. Sci Rep [Internet]. 2017 Mar 23;7:45219. Available from: http://www. ncbi.nlm.nih.gov/pmc/articles/PMC5362892/. doi: 10.1038/srep45219

9. Mengual L, Burset M, Marín-Aguilera M, Ribal MJ, Alcaraz A. Multiplex preamplification of specific cDNA targets prior to gene expression analysis by TaqMan Arrays. BMC Res Notes. 2008;1:21. doi: 10.1186/1756-0500-1-21

10. Lekanne Deprez RH, Fijnvandraat AC, Ruijter JM, Moorman AF. Sensitivity and accuracy of quantitative real-time polymerase chain reaction using SYBR green I depends on cDNA synthesis conditions. Anal Biochem [Internet]. 2002;307(1):639. Available from: http://www.sciencedirect.com/ science/article/pii/S0003269702000210 